\title{
FORENSIC STUDY FOR DETERMINATION OF THE INCIDENCE OF PERSISTENT METOPIC (FRONTAL) SUTURE AND ITS RELATION TO AGE AND SEX AMONG SAMPLE OF EGYPTIAN SKULLS
}

\author{
Azza Wagih Zanaty \\ Forensic Medicine and Clinical Toxicology, Faculty of Medicine \\ Menoufia University.
}

\begin{abstract}
Introduction: At birth the frontal bone contains two portions, separated by the metopic (frontal) suture. Metopism is the condition of having a persistent metopic suture. Aim of the present study was to determine the incidence of persistence of metopic suture, their shape and its relation to age and sex in Egyptian human skulls. Material and Method: The study was conducted on 147 human dry skulls which belong to the museum of the department of Anatomy, Faculty of Medicine, Menoufia University. The metopic sutures were classified as complete and incomplete types. Incomplete metopic sutures were divided into three groups as present in the lower part of the frontal bone, in the upper part and in the middle part. The incomplete lower metopic sutures were further subdivided into linear, ' $V$ ' shaped and ' $U$ ' shaped. Results: From this study, absence metopic sutures were observed in 84 (57.1\%) skulls, while it was present in $63(42.9 \%)$ ones. The complete metopic suture (metopism) was seen in $12(8.2 \%)$ skulls and incomplete one in 51 (34.7\%). Among the incomplete ones, linear, ' $\mathrm{U}$ ' and ' $\mathrm{V}$ ' shaped was found in $36(24.5 \%), 9(6.1 \%)$, and $6(4.1 \%)$, respectively. All incomplete metopic sutures were found in the lower part of frontal bone, but no suture remnant was found in the upper and middle part of frontal bone. Incomplete lower V shaped metopic suture presented in all female skulls. There were statistical significant relation between absent, complete, incomplete lower linear and incomplete lower $\mathrm{V}$ shaped metopic suture regarding age. Also there was statistical significant relation between metopism regarding age and sex. There was sensitivity and specificity for both age and sex with metopic suture. Conclusion and recommendation: The incidence of metopism was $8.2 \%$ while incomplete metopic sutures were $34.7 \%$. This incidence may be valuable information for identification of the person and for radiologists and neurosurgeons in practice to concern about metopic suture in emergency diagnosis of frontal bone fractures.
\end{abstract}

Key words: Incidence, skull, metopic suture.

\section{INTRODUCTION}

The frontal bone of the skull is divided into two halves by a fibrous metopic (frontal) suture (Vu et al., 2001). It is typically dentate suture when it is persistent and lies $2 \mathrm{~cm}$ anterior to the coronal suture. The posterior end of it does not meet the sagittal suture and away by $15 \mathrm{~mm}$.

Egypt J. Forensic Sci. Appli. Toxicol
(Keith and Persaud, 2003; Yadav et al., 2010). The obliteration of metopic suture is controversial (Bilgin et al., 2013). It begins to unite in the second year, and completely fuses by the $8^{\text {th }}$ year. The approximate closuring time of the metopic suture is 2 years of age (Scheuer and Black, 2000; Bademci et al., 2007; Bajwa et al., 2013). 
Partial or total failure of closure of metopic suture and its difference in shape may be present in some skulls which show racial variation (Eroglu, 2008). Metopism is the complete persistence of the metopic suture in adult individuals and its frequency

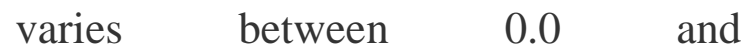
$13.0 \%$ (Hanihara and Ishida, 2001). Faro et al., (2006) reported that in Apert syndrome (a congenital disorder characterized by malformations of the skull, face, hands and feet) there was an impaired closure of the metopic suture. The most accepted cause is the genetic influence (Castilho et al., 2006). The dura matersuture complex had a critical role in determining metopic suture patency in animal models (Bademci et al., 2007). Longaker (2001) indicated that some cytokines showed increased expression during active cranial suture fusion. Chondroid tissue is responsible for suture closure and maintenance of an open suture occurs by the process of active resorption (Murlımanju et al., (2011). Persistent frontal sutures are of no clinical significance, although they can be mistaken for cranial fractures (Weir et al., 2006). In radiological images it can be misunderstood as fracture of frontal bone or even for the sagittal suture (Santhosh et al., 2014). Diagnosing the persistent suture clinically in suspected head trauma patient may be problematic as it may be considered an evidence of traumatic vertical fractures (Aksu et al., 2014). Multiplanar reformat 3D CT scans are helpful to demonstrate the type and extent of the suture and to verify the pathology (Bademci et al., 2007). Incidence of persistence of metopic suture in different races is important for paleodemography and forensic medicine (Santhosh et al., 2014).
Aim of The Work: to determine the incidence of persistence of metopic sutures, their shape, and the relation between metopic suture to age and sex in Egyptian human skulls.

\section{MATERIAL \& METHODS}

The study was conducted on 147 dried identified human skulls (78 males and 69 females) aged 30 - >50 years old. They were obtained from the museum of Anatomy department, Faculty of Medicine, Menoufia University. All the skulls were free from any deformities or trauma. The skulls were examined by naked eye for the presence or absence of the metopic suture. The skulls were divided into three groups as normal skulls without metopic suture, complete metopic suture (metopism) as it is found completely extended between the bregma and nasion and with incomplete metopic suture when it extends to a smaller distance either from the bregma or from the nasion (Skrzat et al., 2004). The incomplete metopic sutures were divided into upper, middle and lower according to their position in the frontal bone. The incomplete metopic sutures in the lower part of the frontal bone were subdivided into different shapes linear, U shaped and $\mathrm{V}$ shaped types (Castilho et al., 2006). The Data were recorded, tabulated and statistically analyzed by computer based statistical package SPSS version 16. The incidence and shape of the metopic suture were analyzed as number and percentage and Chi-square test $\left(\chi^{2}\right)$ was used to study association between two qualitative variables. Pvalue of $<0.05$ was considered statistically significant. Receiver Operating Characteristic (ROC) curve was done to detect cut level of any tested variable where at this level there 
is the best sensitivity and specificity. The validity of the model was measured by means of the concordance $(C)$ statistic (equivalent to the area under the ROC curve). A model with a $c$ value above 0.7 is considered useful while a c value between 0.8 and 0.9 indicated excellent diagnostic accuracy (Elliott and Woodward, 2007). The study was carried out in an ethical manner following guidelines set by the Ethical Committee of Menoufia University.

\section{RESULTS}

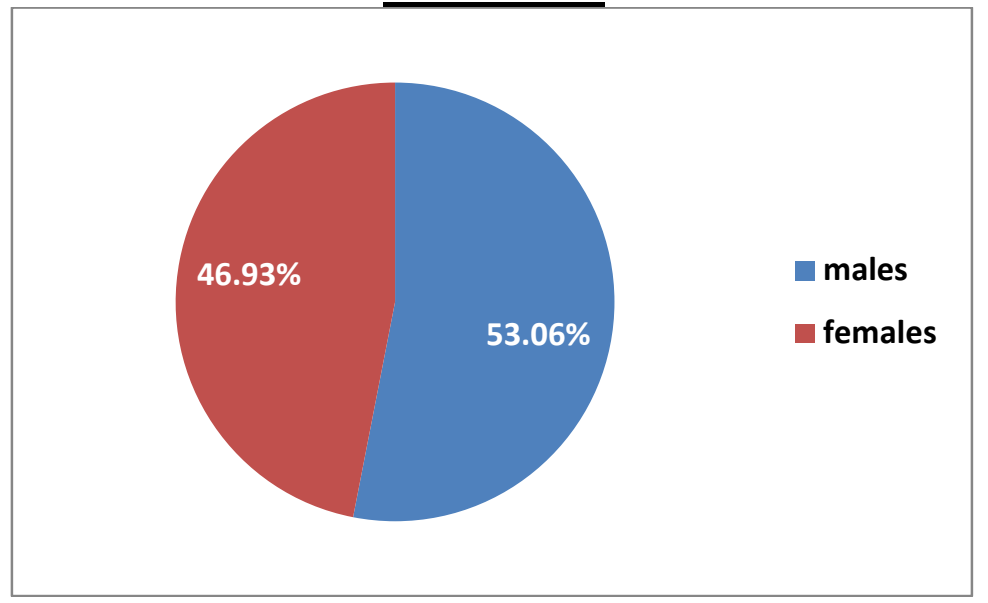

Chart (1): Percentages of Metopic Suture among Males and Females Skulls. No= 147

Table (1): Distribution of the Studied Skulls According to Age.

\begin{tabular}{|l|l|l|}
\hline Age & No. & $\%$ \\
\hline$>30-\leq 40$ & 3 & 2.0 \\
\hline$>40-\leq 50$ & 18 & 12.2 \\
\hline$>50$ & 126 & 85.7 \\
\hline
\end{tabular}

No $=147$

Chart and table (1): show total aged $>50$ years, while (12.2\%) and number of observed skulls was 147 , where $78(53.1 \%)$ skulls were males and $69(46.9 \%)$ skulls were females. $(2 \%)$ of the skulls were in the age groups $(>40-\leq 50)$ and $(>30-\leq 40)$ years respectively. The majority of the skulls $(85.7 \%)$ were

Table (2): Incidence of Metopic Sutures in Males and Females Skulls.

\begin{tabular}{|c|c|c|c|c|c|c|}
\hline \multirow[t]{3}{*}{ Types of metopic suture } & \multicolumn{6}{|l|}{ Sex } \\
\hline & \multicolumn{2}{|c|}{ Male } & \multicolumn{2}{|c|}{ Female } & \multicolumn{2}{|c|}{ Total } \\
\hline & No. & $\%$ & No. & $\%$ & No. & $\%$ \\
\hline Absence of metopic suture & 48 & 57.1 & 36 & 42.9 & 84 & 57.1 \\
\hline Complete (metopism) & 6 & 50.0 & 6 & 50.0 & 12 & 8.2 \\
\hline Incomplete & 24 & 47.1 & 27 & 52.9 & 51 & 34.7 \\
\hline Total & 78 & 53.06 & 69 & 46.9 & 147 & 100.0 \\
\hline
\end{tabular}

Table 2: shows absence of metopic suture (fig.1) was observed in $84(57.1 \%)$ skulls, more than fifty percent was males. Complete metopic suture (metopism) (fig. 2) was presented in $12(8.2 \%)$ skulls which were equally distributed between males and females, while incomplete metopic suture was found in $51(34.7 \%)$ skulls where, $52.9 \%$ of them were females. 
Table (3): Incidence of Types of Incomplete Metopic Sutures in Males and Females Skulls.

\begin{tabular}{|l|lcc|lc|lc|}
\hline Types of incomplete metopic suture & \multicolumn{2}{|l|}{ Males } & \multicolumn{2}{l|}{ Females } & \multicolumn{2}{l|}{ Total } \\
& No. & \% & No. & \% & No. & \% \\
\hline Linear & 21 & 14.3 & 15 & 10.2 & 36 & 24.5 \\
\hline U shaped & 3 & 2.0 & 6 & 4.1 & 9 & 6.1 \\
\hline V shaped & 0 & 0.0 & 6 & 4.1 & 6 & 4.1 \\
\hline In lower part of frontal bone & 24 & 16.3 & 27 & 18.4 & 51 & 34.7 \\
\hline In upper part of frontal bone & 0 & 0 & 0 & 0 & 0 & 0 \\
\hline In middle part of frontal bone & 0 & 0 & 0 & 0 & 0 & 0 \\
\hline
\end{tabular}

No=147

Table (3): shows incomplete metopic sutures in the lower part of frontal bone were presented in 51 $(34.7 \%)$ of skulls. Of them $18.4 \%$ were females. Linear, $\mathrm{U}$ and $\mathrm{V}$ shaped metopic sutures were observed in
$24.5 \%, \quad 6.1 \%$ and $4.1 \%$ skulls respectively (figs. 3,4 and 5). Incomplete metopic sutures in upper and middle part of frontal bone didn't present in the studied skulls.

Table (4): Chi-square $\left(\mathrm{X}^{2}\right)$ Statistical Analysis of Types of Metopic Suture in Relation to Sex.

\begin{tabular}{|l|lr|lr|l|l|l|}
\hline Type of metopic suture & \multicolumn{2}{|l|}{ Male } & \multicolumn{2}{l}{ Female } & Total & X2 & P \\
& No. & No. $\%$ & & & value \\
\hline Absent & 48 & 57.1 & 36 & 42.9 & 84 & 1.3 & 0.16 \\
\hline Complete (metopism) & 6 & 50.0 & 6 & 50.0 & 12 & 0.049 & 0.5 \\
\hline Incomplete lower linear & 21 & 58.3 & 15 & 41.7 & 36 & 0.53 & 0.29 \\
\hline Incomplete lower U shaped & 3 & 33.3 & 6 & 66.7 & 9 & 1.5 & 0.19 \\
\hline Incomplete lower V shaped & 0 & 0.0 & 6 & 100.0 & 6 & 7.07 & $0.009 * *$ \\
\hline
\end{tabular}

\section{No=147 $\quad \mathrm{P}>0.05$ non -significant $* * \mathbf{P}<0.001$ highly significant}

Table (4): shows that incomplete lower V shaped metopic suture presented in all female skulls. The relation between incomplete lower $\mathrm{V}$ shaped metopic suture and sex was highly statistically significant as $\mathrm{P}=0.009$. There were no statistical significant differences between other types of metopic suture regarding sex.

Table (5): Chi-square $\left(\mathrm{X}^{2}\right)$ Statistical Analysis of Types of Metopic Suture in Relation to Age.

\begin{tabular}{|c|c|c|c|c|c|c|c|c|c|}
\hline \multirow[t]{2}{*}{ Type of metopic suture } & \multicolumn{2}{|c|}{$\begin{array}{l}>30-\leq 40 \\
(\mathrm{~N}=3)\end{array}$} & \multicolumn{2}{|c|}{$\begin{array}{l}>40-\leq 50 \\
(N=18)\end{array}$} & \multicolumn{2}{|c|}{$\begin{array}{l}>50 \\
(N=126)\end{array}$} & \multirow{2}{*}{$\begin{array}{l}\text { Total } \\
\text { No. }\end{array}$} & \multirow[t]{2}{*}{$\mathrm{X} 2$} & \multirow{2}{*}{$\begin{array}{l}\mathrm{P} \\
\text { value }\end{array}$} \\
\hline & No. & $\%$ & No. & $\%$ & No. & $\%$ & & & \\
\hline Absent & 0 & 0.0 & 6 & 7.1 & 78 & 92.9 & 84 & 9.3 & $0.009 * *$ \\
\hline Complete (metopism) & 3 & 25.0 & 6 & 50.0 & 3 & 25.0 & 12 & 54.6 & $0.00 * *$ \\
\hline Incomplete lower linear & 0 & 0.0 & 0 & 0.0 & 36 & 100.0 & 36 & 7.9 & $0.019 *$ \\
\hline Incomplete lower U shaped & 0 & 0.0 & 3 & 33.3 & 6 & 66.7 & 9 & 4.08 & 0.13 \\
\hline Incomplete lower $\mathrm{V}$ shaped & 0 & 0.0 & 3 & 50.0 & 3 & 50.0 & 6 & 8.3 & $0.015^{*}$ \\
\hline
\end{tabular}

No=147 $\quad \mathrm{P}>0.05$ non -significant $* \mathbf{P}<0.05$ significant $* * \mathrm{P}<0.001$ highly significant 
Table (5): reveals that absent metopic suture and incomplete lower linear metopic suture were $92.9 \%$ and $100 \%$ and $\mathrm{P}=0.009$ and 0.019 respectively in age group $(>50)$ years. Metopism presented in fifty percent of skulls in age group $(>40-\leq 50)$ years. The relation between metopism and age was highly statistically significant as $\mathrm{P}=0.00$ Incomplete lower $\mathrm{V}$ shaped metopic suture was equally distributed in age groups $(>30-\leq 40)$ years and $(>50)$ years. The relation between incomplete lower $\mathrm{V}$ shaped metopic suture and age was statistically significant as $\mathrm{P}=0.015$. Furthermore, there was no significant statistical relation between type of incomplete lower U shaped metopic suture and age as $\mathrm{P}=0.13$

Table (6): Chi-square $\left(\mathrm{X}^{2}\right)$ Statistical Analysis of Types of Metopic Suture in Relation to Age and Sex.

\begin{tabular}{|c|c|c|c|c|c|c|c|c|c|}
\hline \multirow{2}{*}{$\begin{array}{l}\text { Type of } \\
\text { metopic } \\
\text { suture }\end{array}$} & \multicolumn{2}{|c|}{$>30-\leq 40$} & \multicolumn{2}{|c|}{$>40-\leq 50$} & \multicolumn{2}{|l|}{$>50$} & \multirow{2}{*}{$\begin{array}{l}\text { Tot } \\
\text { al } \\
\text { No. }\end{array}$} & \multirow[t]{2}{*}{$\mathrm{X} 2$} & \multirow{2}{*}{$\begin{array}{l}\mathbf{P} \\
\text { value }\end{array}$} \\
\hline & $\begin{array}{l}\text { Male } \\
\text { No. \% }\end{array}$ & $\begin{array}{l}\text { Female } \\
\text { No. \% }\end{array}$ & $\begin{array}{l}\text { Male } \\
\text { No.\% }\end{array}$ & $\begin{array}{l}\text { Female } \\
\text { No. } \\
\%\end{array}$ & $\begin{array}{l}\text { Male } \\
\text { No. \% }\end{array}$ & $\begin{array}{l}\text { Female } \\
\text { No. \% }\end{array}$ & & & \\
\hline Absent & $\begin{array}{ll}0 & 0.0\end{array}$ & $\begin{array}{ll}0 & 0.0\end{array}$ & 33.6 & 33.6 & 4553.6 & 3339.3 & 84 & 0.135 & 0.52 \\
\hline $\begin{array}{l}\text { Complete } \\
\text { (metopism) }\end{array}$ & 325.0 & $\begin{array}{ll}0 & 0.0\end{array}$ & 325.0 & $3 \quad 25.0$ & $\begin{array}{ll}0 & 0.0\end{array}$ & 325.0 & 12 & 6 & $0.039 *$ \\
\hline $\begin{array}{l}\text { Incomplete } \\
\text { lower } \\
\text { linear }\end{array}$ & $\begin{array}{ll}0 & 0.0\end{array}$ & $\begin{array}{ll}0 & 0.0\end{array}$ & $\begin{array}{ll}0 & 0.0\end{array}$ & 0.0 & 2158.3 & 1541.7 & 36 & --- & --- \\
\hline $\begin{array}{l}\text { Incomplete } \\
\text { lower U } \\
\text { shaped }\end{array}$ & $\begin{array}{ll}0 & 0.0\end{array}$ & $\begin{array}{ll}0 & 0.0\end{array}$ & $\begin{array}{ll}0 & 0.0\end{array}$ & $\begin{array}{ll}3 & 33.3\end{array}$ & 333.3 & $\begin{array}{ll}3 & 33.3\end{array}$ & 9 & 2.2 & 0.23 \\
\hline $\begin{array}{l}\text { Incomplete } \\
\text { lower V } \\
\text { shaped } \\
\end{array}$ & $\begin{array}{ll}0 & 0.0\end{array}$ & $\begin{array}{ll}0 & 0.0\end{array}$ & $\begin{array}{ll}0 & 0.0\end{array}$ & 350.0 & $\begin{array}{ll}0 & 0.0\end{array}$ & 350.0 & 6 & -- & -- \\
\hline
\end{tabular}

No=147 $\mathrm{P}>0.05$ non -significant $* \mathrm{P}<0.05$ significant

Table (6): shows that complete metopic suture (metopism) equally distributed between males and females $(25 \%)$ each in age group $(>40-\leq 50)$ years while it was in all males in age group $(>30-\leq 40)$ years. The relation between metopism regarding age and sex was statistical significant as $\mathrm{P}=0.039$. On the other hand there were not significant statistical differences between other types of metopic suture regarding age and sex. 


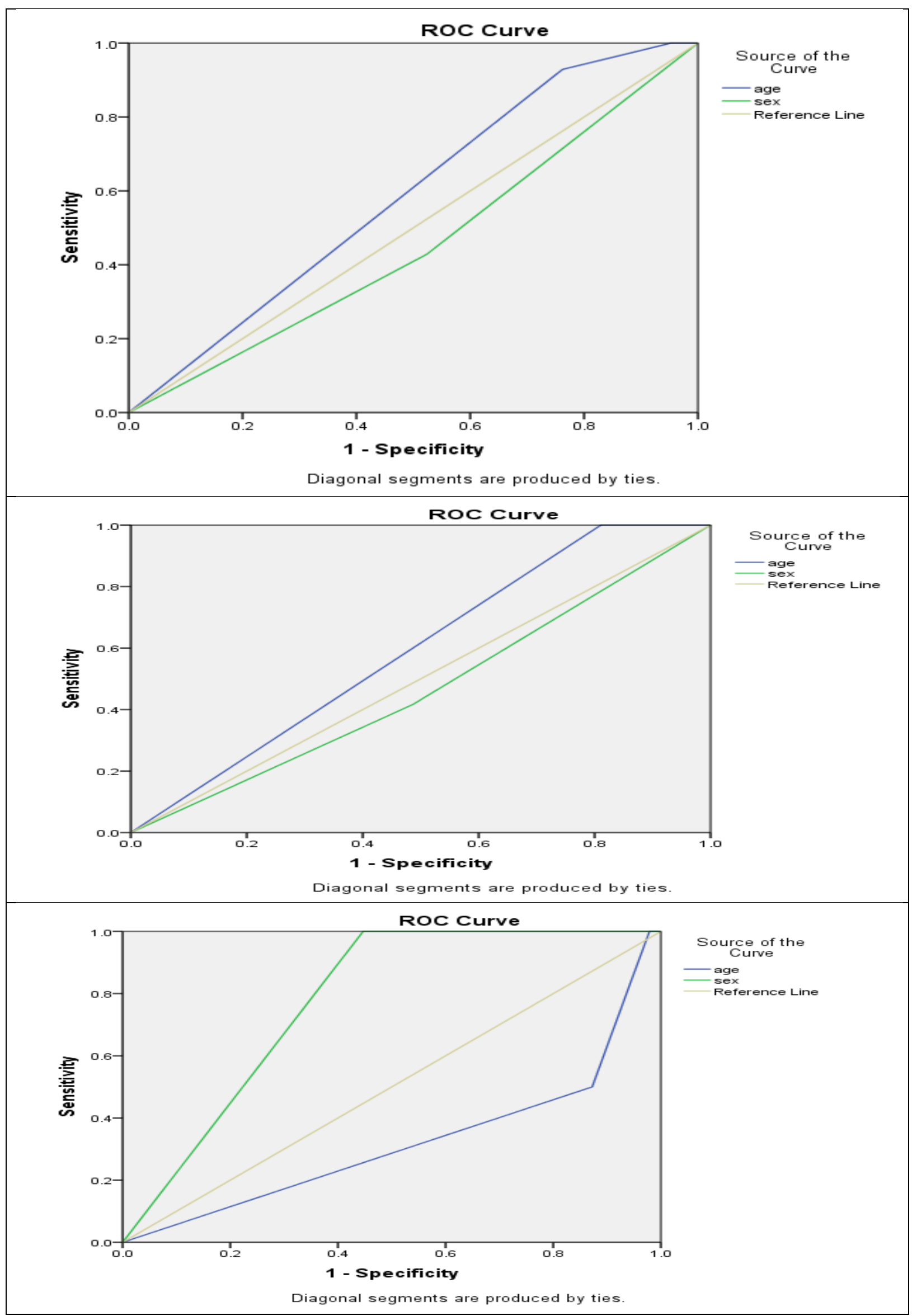

Chart (2): Receiver Operating Characteristic (ROC) curves. 
Table (7): Sensitivity and Specificity of Age and Sex as Predictive Variables for Metopic Suture.

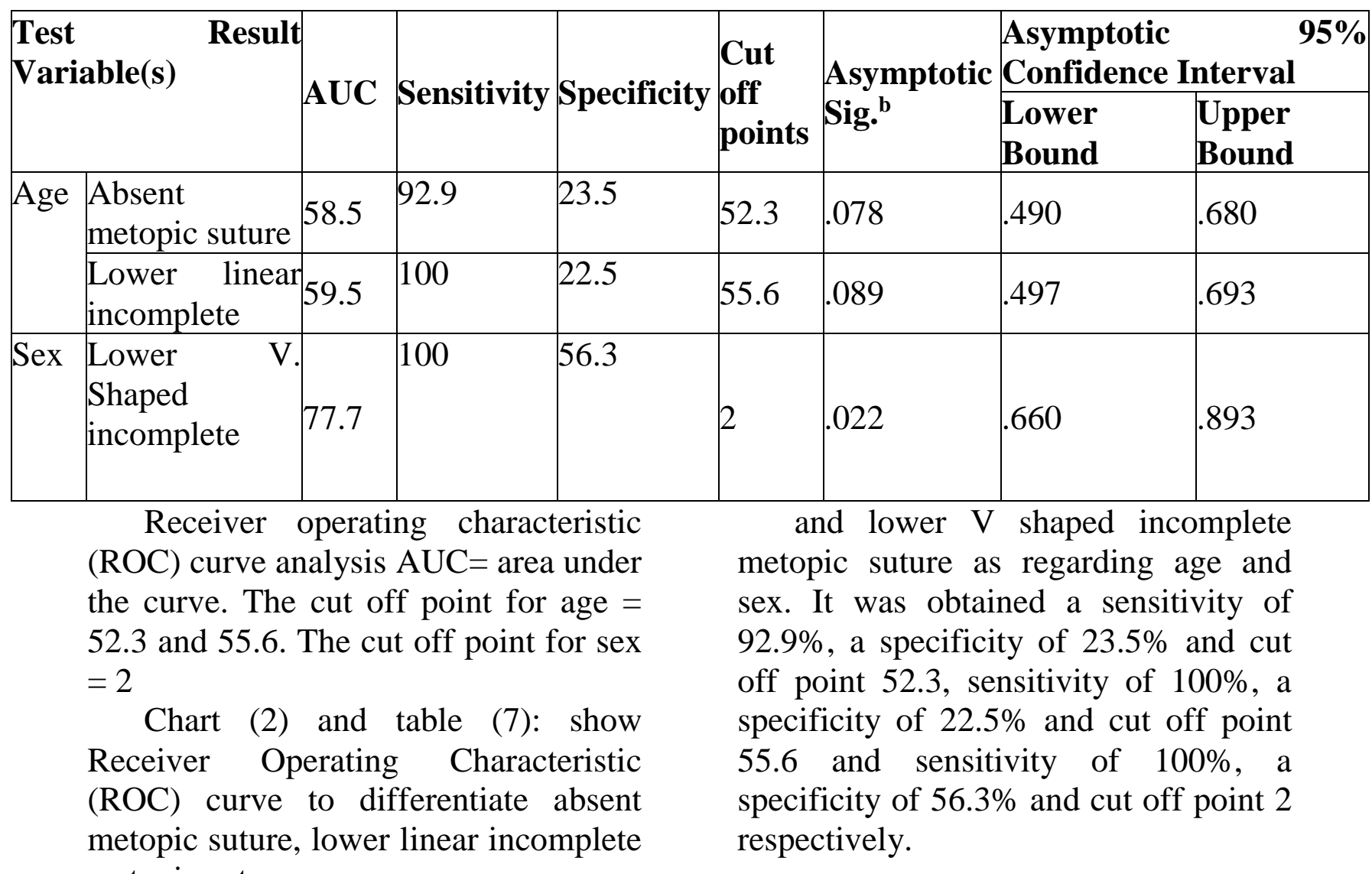

metopic suture

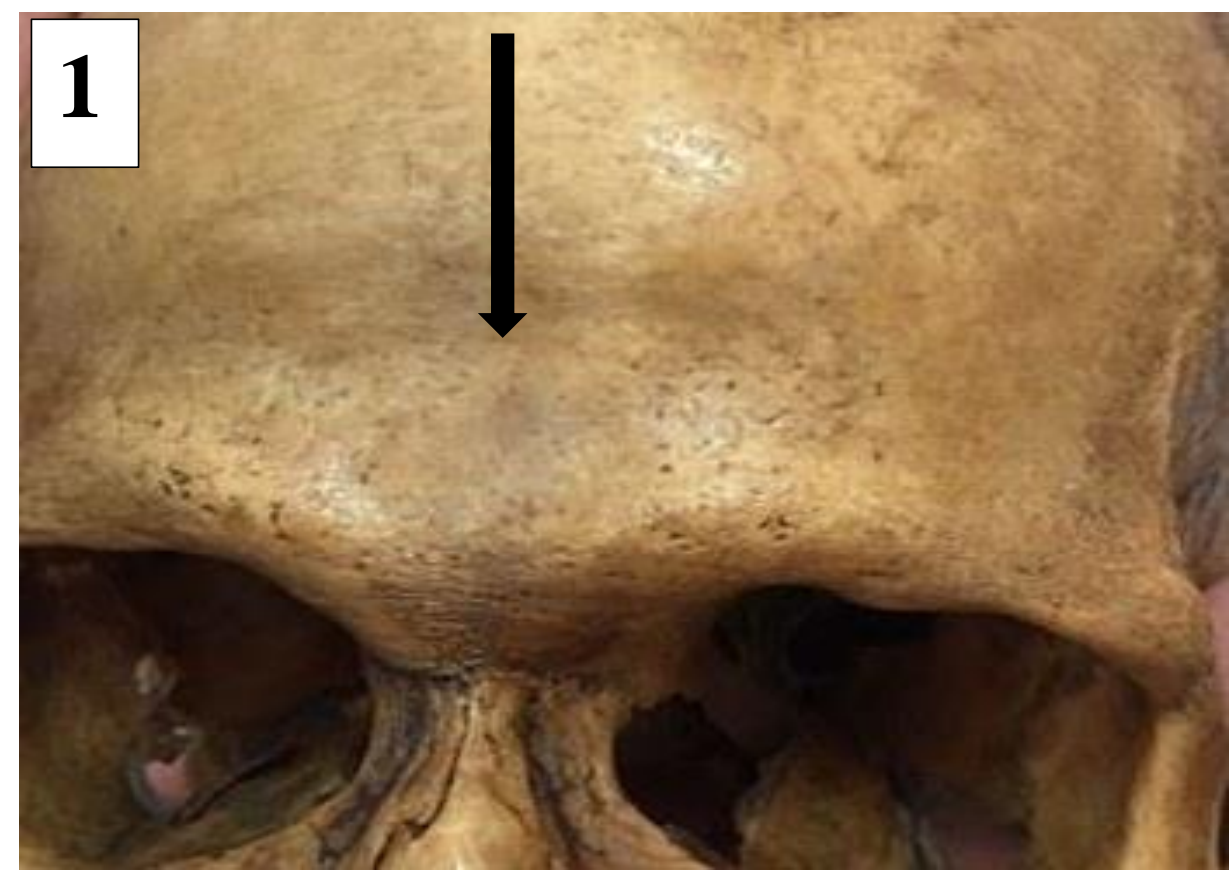

Figure (1): Showing absence of metopic suture (Arrow). 


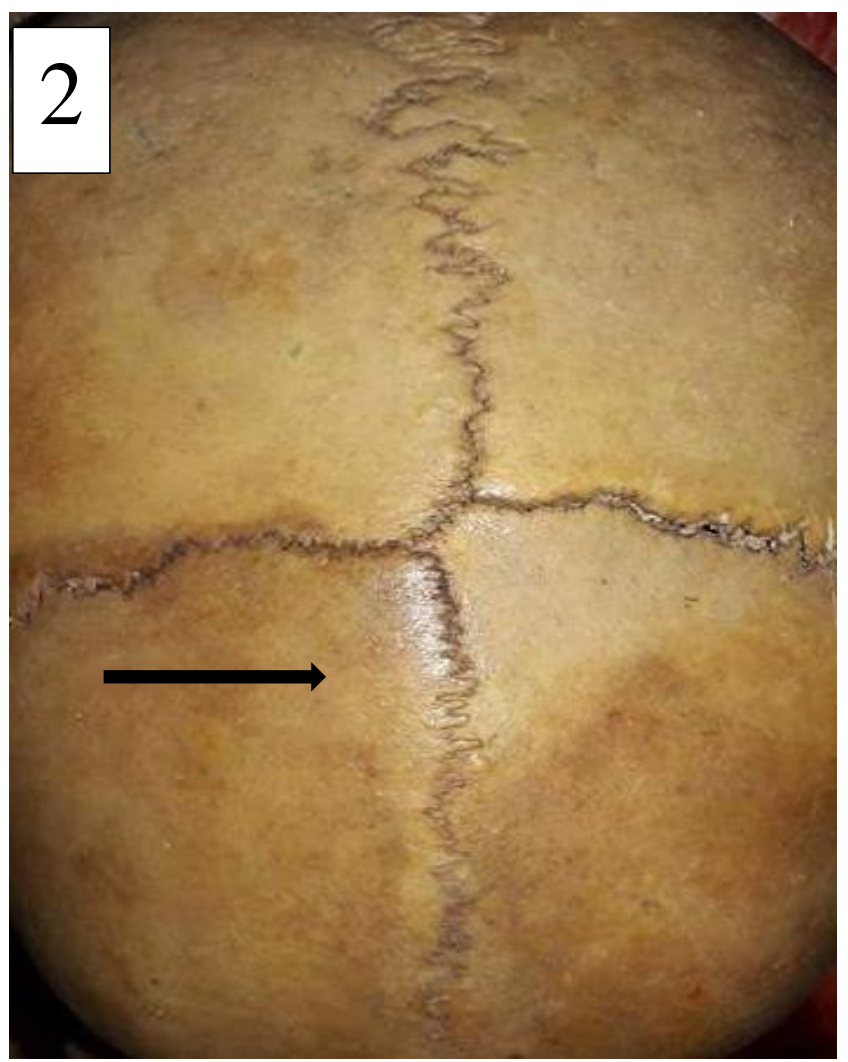

Figure (2): Showing Complete metopic suture (Arrow).

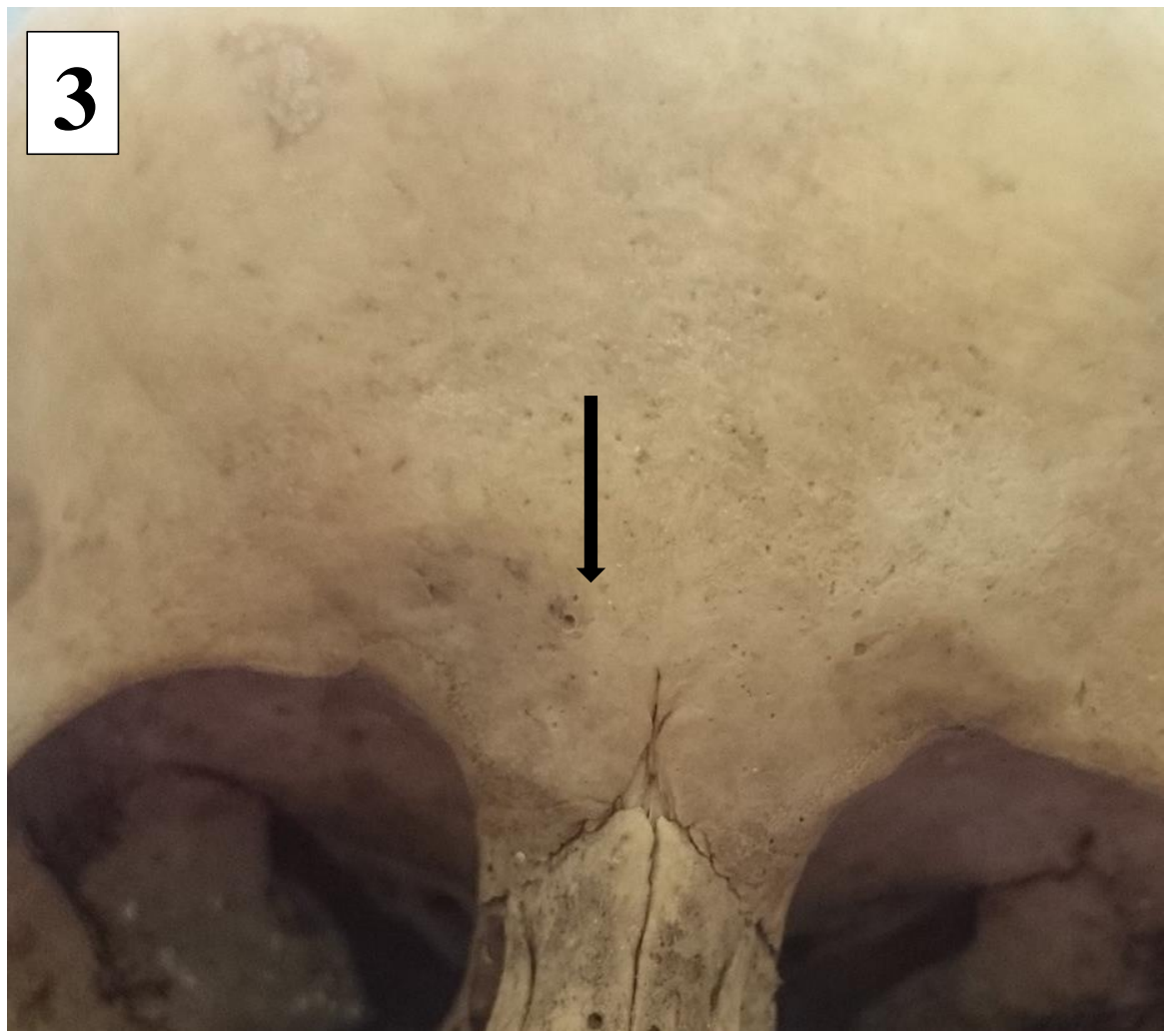

Figure (3): Showing linear lower metopic suture (incomplete) (Arrow). 


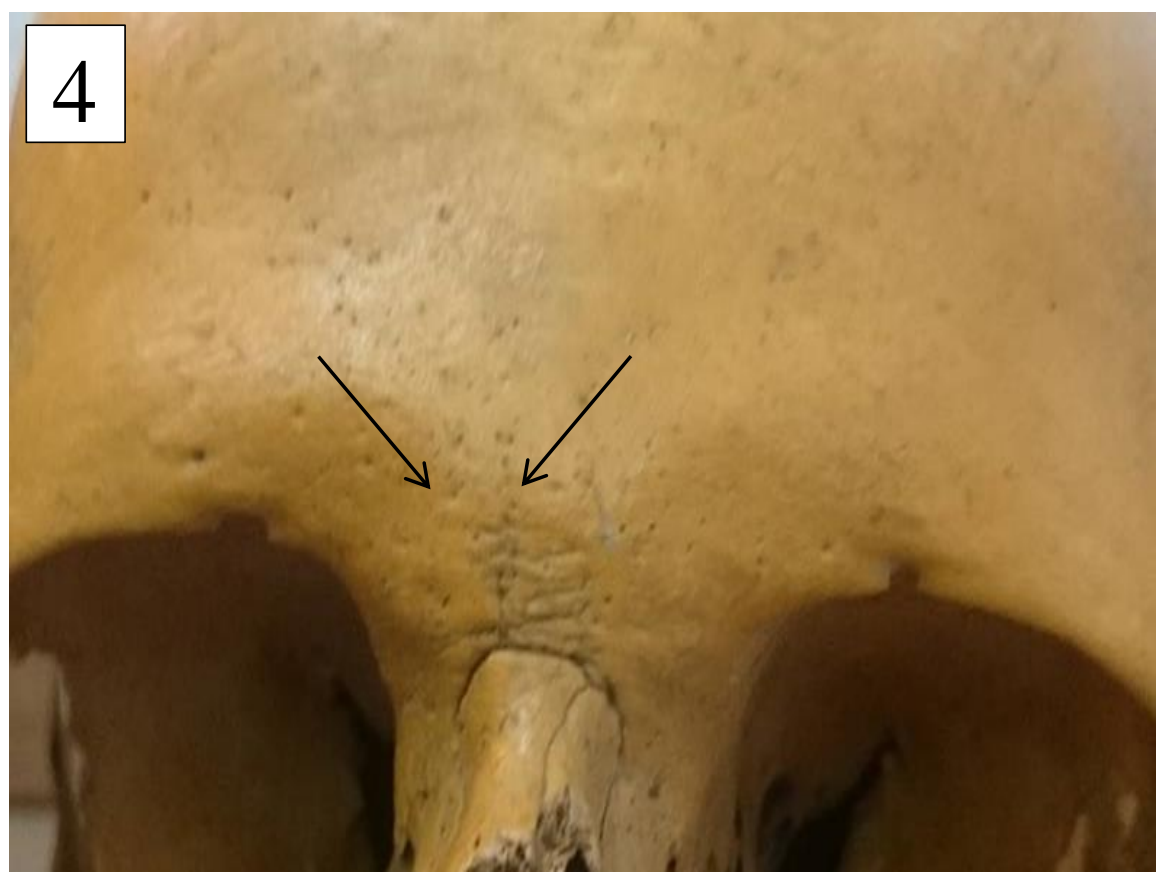

Figure 4: Showing U shaped lower metopic suture (incomplete) (Arrows).

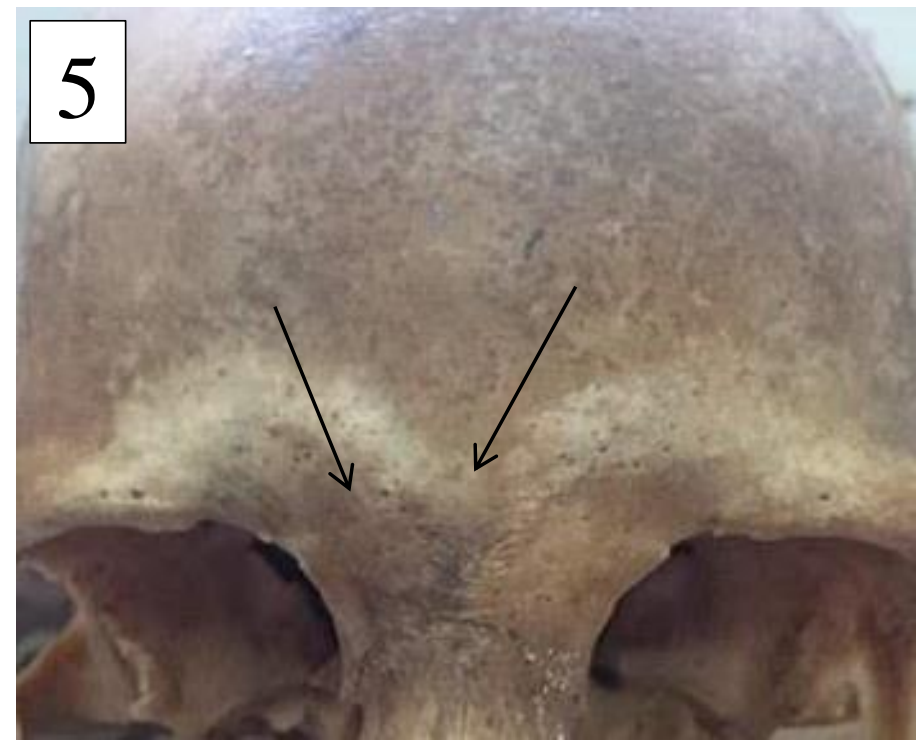

Figure (5): Showing V shaped lower metopic suture (incomplete) (Arrows).

\section{DISCUSSION}

Metopic suture is a kind of dentate suture extending from the nasion to the bregma. Its timing of closure is still controversial. The etiology of persistent metopic suture is unclear. Skrzat et al., (2004) reported that, it is difficult to find difference between shapes of skulls with or without metopic sutures

as there is a lake of suitable data. According to Del Sol et al., (1989) metopism can be due to abnormal growth of cranial bones, growth retardation, heredity, atavism, hydrocephalus, sexual influence, mechanical causes and hormonal dysfunction.

This study aimed to determine incidence, shape and extent of metopism in Egyptian population skulls sample. The metopic sutures in the present study were observed in $42.9 \%$ of the skulls. Among them 78 (53.1\%) were seen in males and 69 (46.9\%) in 
females. Similar male preponderance of metopic sutures was observed earlier by Baaten et al., (2003) in Labanise, Murlımanju et al., (2011) in Indian and Khamanarong et al., (2015) in Thai skulls. Maximum incidence of metopic suture was reported by Murlmanju et al., (2011), as $64.1 \%$ in Indian skulls.

In the present study complete metopic suture (metopism) was determined as $8.2 \%$ and equally distributed between male and female skulls. This result was similar to earlier study carried by Skrzat et al., (2004) in Europeans as $7-10 \%$ but it was higher than the incidence reported by other workers. Castilho et al., (2006) observed the occurrence of metopism in $7.04 \%$ of the Brazalian skulls, of which $80 \%$ were female and $20 \%$ male. Santhosh et al., (2014) reported that the incidence of metopism in south Indian was found to be 6\%. Murlmanju et al., (2011) reported that the incidence of metopism in Indian was determined as $1.2 \%$. The highest incidence of metopism was reported in Alpine skulls as $63.2 \%$ (Castilho et al., 2006). According to Baaten et al., (2003), the incidence of metopism was $0.82 \%$ in the Lebanese population.

In the present study, the incidence of incomplete metopic suture was found to be $34.7 \%$ where, $18.4 \%$ of them were females. This coincides to the study conducted by Chakravarthi and Venumadhav (2012) (38.75\%) and ShantaChandrasekaran

and DeeptiShastri (2011) (40\%). But it is in contrast to the study conducted by Yadav et al (2010) (14.6\%) and Santhosh et al. (2014) (7\%). Khamanarong et al., (2015) reported that the incidence of incomplete metopic suture of Thais was higher than that of the complete metopic suture with respect to sex, the metopic suture in both types is found to be higher in males than in females.

All skulls of incomplete metopic suture type $(34.7 \%)$ were observed in the lower part of frontal bone, whereas none of the incomplete metopic suture was observed in the upper and middle part of frontal bone. This is in agreement with previous study by Santhosh et al., (2014) reported incomplete metopic suture in the lower part of frontal bone, whereas none of the incomplete metopic suture was observed in the upper and middle part of frontal bone. On contrast Yadav et al., (2010) reported metopic suture in lower part in $14.02 \%$ skulls, in upper part in $0.39 \%$ and in middle parts in $0.19 \%$ cases. In this study we found linear incomplete metopic suture in $24.5 \%$ of the skulls, ' $U$ ' shaped and ' $\mathrm{V}$ ' shaped in $6.1 \%$ and $4.1 \%$ skulls respectively which is similar to the study conducted by Santhosh et al., (2014) but is in contrast to the study conducted by ShantaChandrasekaran and DeeptiShastri (2011) and Chakravarthi and Venumadhav (2012). Also in the present study, there was found that $\mathrm{V}$ shaped metopic suture presented in all female skulls. This is different from the study carried by Murlımanju et al., (2011) who observed that males were higher incidence than females.

In this study there was significant statistical relation between metopism regarding age and sex. Complete metopic suture (metopism) equally distributed between males and females in age group $(>40-\leq 50)$ years but, it presented in all males in age group $(>30-\leq 40)$ years. This is different from others studies, Santhosh et al., (2014) found that the incidence of metopism was slightly higher in the female 
population and Khamanarong et al., (2015) found that this incidence was higher in males than in females.

The present study showed ROC curve differentiate absent metopic suture and lower linear incomplete metopic suture regarding age and lower $\mathrm{V}$ shaped incomplete metopic suture regarding sex. Perkins and Schisterman (2006) and Akobeng (2007) stated that there are several advantages by using ROC curve. The diagnostic accuracy from this analysis is based on sensitivity and specificity which can easily obtained by visualizing the curve (Greiner et al., 2000; Morton et al., 2001)

Conclusion and recommendations

The present study has shown the incidence of metopic suture in Egyptian skulls as $42.9 \%$ and metopism as $8.2 \%$. The most common incomplete metopic suture was linear type in the lower part of the frontal bone. The relation between incomplete lower $\mathrm{V}$ shaped metopic suture and sex was highly statistically significant as it presented in females skulls. There were highly significant relation between absent metopic suture and metopism regarding age. There was significant statistical relation between metopism regarding age and sex where, it presented in all males in age group $(>30-\leq 40)$ years. There was sensitivity and specificity for both age and sex with absent metopic suture, lower liner incomplete and lower V-shaped metopic suture respectively. So the study would be a useful guide for forensic medicine experts in the identification of a person. Due to lake of the availability of the skulls, a lesser number of sample sizes were taken in this study. Larger sample size can be done for better analysis and helpful constructive data.

\section{ACKNOWLEDGEMENT}

I would like to thank Department of Anatomy, Faculty of Medicine, Menoufia University for providing the identified human skulls.

\section{REFERENCES}

Akobeng, A.K. (2007): Understanding diagnostic test 3: Receiver operating characteristic curves. Acta Paediatr. 90:644-647.

Aksu, F.; Cirpan, S.; Mas, N.G.; Karabekir, S. and Magden, A.O. (2014): Anatomic features of metopic suture in adult dry skulls. J CraniofacSurg. 25(3):1044-1046.

Baaten, P.J.; Haddad, M.; Abi-Nader, K.; Abi-Ghosn, A.; Al-Kutoubi, A. and Jurjus, A.R. (2003): Incidence of metopism in the Lebanese population. Clin Anat 6:148-151,

Bademci, G.; Kendi, T. and Agalar, F. (2007): "Persistent metopic suture can mimic the skull fractures in the emergency setting?". Neurocirugía, 18: 238240

Bajwa,M.; Srinivasan,D.; Nishikawa, H.; Rodrigues,D.; Solanki,G.and White, N. (2013): Normal fusion of the metopic suture. J Craniofac Surg. 24:1201-1205.

Bilgin, S.; Kantarcı, U. H.; Duymus, M.; Yildirim, C. H.; Ercakmak, B.; Orman, G.; Gunenc Beser, C.; Kaya, M.; Gok, M. and Akbasak, A. (2013): Association between frontal sinus development and persistent metopic suture. Folia Morphol. (Warsz.), 72(4):306-310.

Castilho, S.M.; Oda, Y.J. and Santana, G.D. (2006): Metopism in adult skulls from Southern Brazil. Int J Morphol, 24:61-66.

Chakravarthi, K.K. and Venumadhav, N. (2012):

Vol 17 (1) June 2017 
Morphological study of Metopic suture in adult South Indian skulls, Int J Med Health Sci, 1(2):7-12.

Del Sol, M.; Binvignat, O.; Bolini, P.D.A. and Prates, J.C. (1989): Metopismo no individuo brasileiro. Rev. Paul. Med, 107(2):105-107.

Elliott, A. and Woodward, W. (2007): SPSS (Statistical package of the social sciences, SAGE publications. California, London and New Delhi, printed in USA.

Eroglu, S. (2008): The frequency of metopism in Anatolian populations dated from the Neolithic to the first quarter of the $20^{\text {th }}$ century. Clin Anat 21: 471-478.

Faro, C.; Chaoui, R.; Wegrzyn, P.; Levaillant, J.M.; Benoit, B. and Nicolaides, K.H. (2006): Metopic suture in fetuses with Apert syndrome at 22-27 weeks of gestation. Ultrasound Obstet Gynecol. 27:28-33.

Greiner, M.; Pfeiffer D. and Smith, R.D. (2000): Principles and practical application of the receiver operating characteristic analysis for diagnostic test. Prev Vet Med. 45:23-41.

Hanihara,T.

and Ishida,

H. (2001): Frequency variations of discrete cranial traits in major human populations. II. Hypostotic variations. J Anat 198:707-725.

Keith, L.M. and Persaud, T.V. (2003): The Developing Human: Clinically Oriented Embryology. 7th ed.Saunders: Philadelphia.P 536.

Khamanarong, K.; Tuamsuk, P.; Woraputtaporn, W.; Namking, M.; Sawatpanich, T.; Toomsan, Y. and Iamsaard, S. (2015): Incidence of metopism in adult Thai skulls. Int. J. Morphol., 33(1):5154.
Longaker, M.T. (2001): Role of TGFbeta signaling in the regulation of programmed cranial suture fusion. $\mathbf{J}$ Craniofac Surg, 12: 389-390.

Morton, R.F.; Hebel, J.R. and McCarter, R.J. (2001): "Medical statistics". In: A study guide to epidemiology and biostatistics $5^{\text {th }}$ ed. Aspen publication, Gaithersburg, Maryland, P 71-74.

Murlımanju, B.V.; Latha, V.; Prabhu Mangala, M.; Paı1, Avlyn Anisha Goveas1, K.V.N. and Dhananjaya, M.S. (2011): Median Frontal Sutures - Incidence, Morphology and Their Surgical, Radiological Importance. Turkish Neurosurgery, 21(4): 489-493.

Perkins, N.J. and Schisterman, E.F. (2006): The inconsistency of optimal cut-points obtained using two criteria based on receiver operating characteristic curve. Am J Epidemiol. 163:670-675.

Santhosh, C.S.; Vishwanathan, K.G.; Gupta, A. and Siddesh, R.C. (2014): Metopic Suture - Incidence and Morphology in South Indian Human Adult Skulls. International Journal of Medical Toxicology and Forensic Medicine. 4(1): 6-10.

Scheuer, L. and Black, S. (2000): Developmental juvenile osteology. San Diego: Academic Press.

ShantaChandrasekaran and DeeptiShastri (2011): A Study on Metopic Suture. International Journal of Basic Medical Science, 1:379-382.

Skrazat, J.; Walocha, J. and Zawilinski, J. (2004): A note on the morphology of the metopic suture in the human skull. Folia Morphol (Warsz) 63:481-484. 
Van der Meulen, J. (2012): Metopic synostosis. Child's Nervous System. 28(9):1359-1367.

Vu, H.; Panchal, J.; Parker, E.; Levine, N. and Francel, P. (2001): "The timing of physiologic closure of the metopic suture: a review of 159 patients using reconstructed 3D CT scans of the craniofacial region". J Craniofac Surg., 12(6): 527-532.
Weir, P.; Suttner, N.J.; Flynn, P. and McAuley, D. (2006): Normal skull suture variant mimicking intentional injury. BMJ 332(7548):1020-1021.

Yadav, A.; Kumar, V. and Srivastava, $\mathbf{R}$.

K. (2010): Study of Metopic suture in the adult human skulls of north India, J. Anat. Soc. India, 59(2) 232-236. 
دراسة شرعية لتحديد مدى وجود الدرز الجبهي وعلاقته بالنوع و العمر في عينة من جماجم المصريين

$$
\text { قسم الطب الثرعي و السموم الإكلينيكية كلية الطب زبنية - جامعة المنوفية }
$$

المقدمة: تحتوي عظمة الجبهة علي جزئين منفصلين بواسطة الدرز الجبهي عند الولادة ـ ويسمي

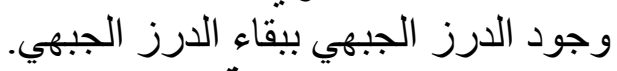

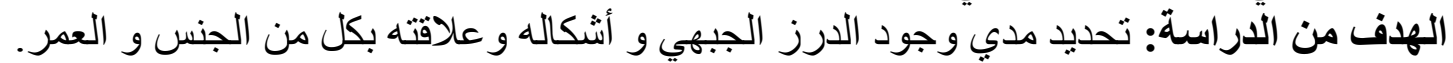

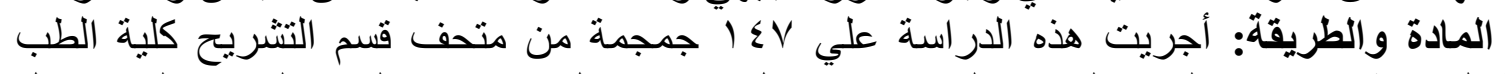

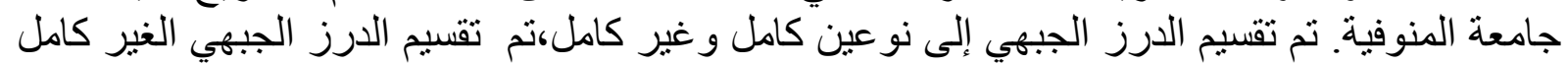

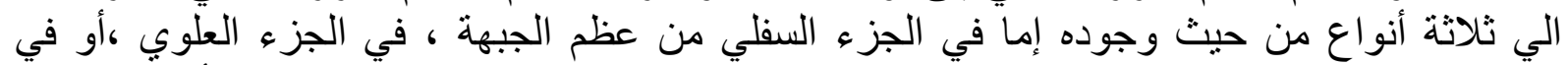

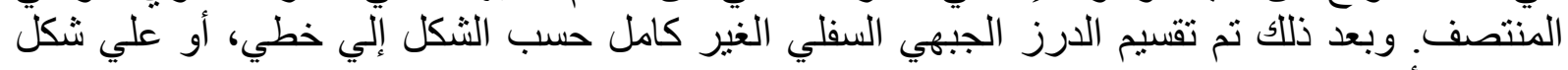

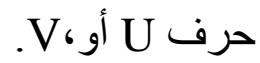

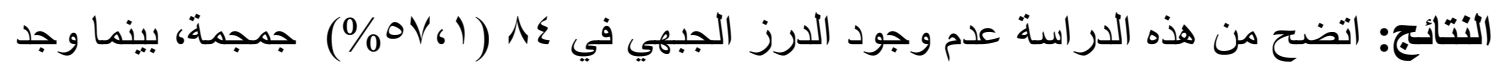

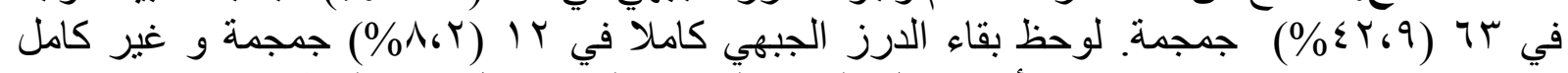

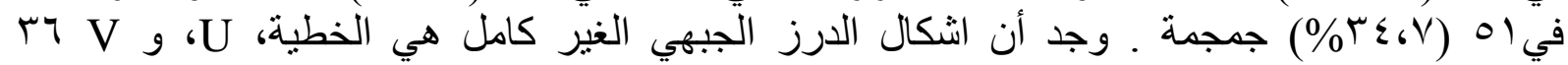

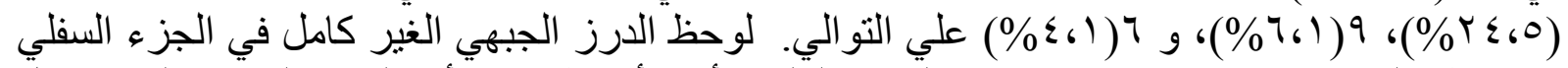

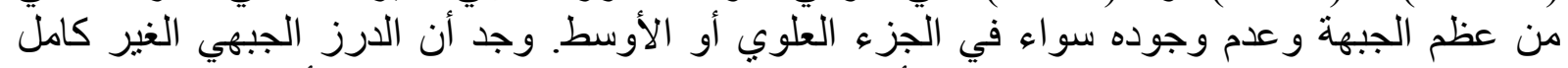

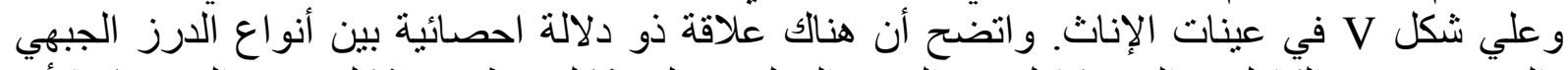

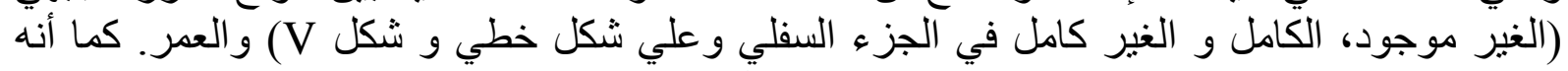

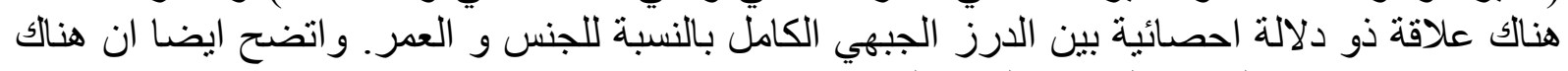

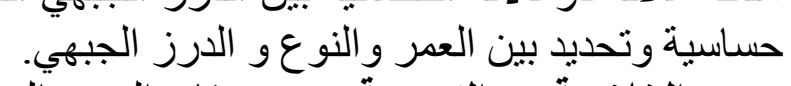

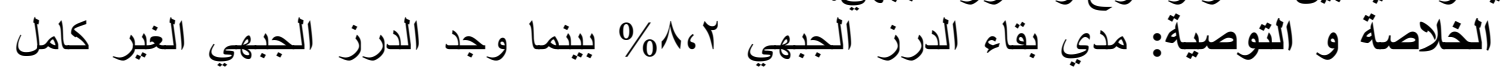

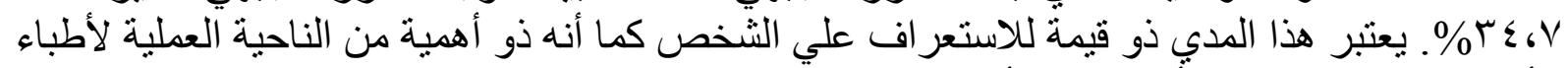

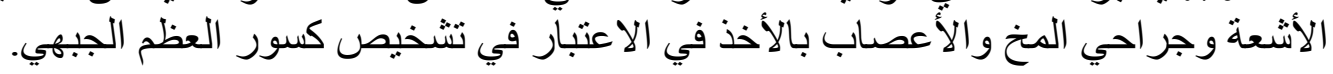

